Joanna Kulwicka-Kamińska ${ }^{1}$, Magdalena LewickA ${ }^{2}$

\author{
${ }^{1}$ Uniwersytet Mikołaja Kopernika \\ Instytut Języka Polskiego \\ ${ }^{2}$ Uniwersytet Mikołaja Kopernika \\ Pracownia Języka i Kultury Arabskiej
}

\title{
Transformacja immanentną cechą przekładu tekstu specjalistycznego - na podstawie polskiego tłumaczenia Koranu z 2. połowy XVI w.
}

Słowa klucze: historia języka polskiego, semantyka, leksykografia, przekład, terminologia religijna

W pracach translatorycznych wyróżnia się zasadniczo dwa typy tekstów - literackie i nieliterackie, czyli informacyjne, specjalistyczne (Grucza 1981: 14; Kielar 1988: 35). K. Reiss (1976: 10) ze względu na dominujące w tekście funkcje językowe dzieli je na teksty przedstawieniowe (informacyjne, np. techniczne, naukowe), w których dominuje aspekt logiczny języka, teksty ekspresywne, w których na pierwszy plan wysuwa się jego funkcja estetyczna i teksty apelatywne, cechujące się dialogowością.

Przekład tekstów literackich zakłada duży margines swobody. Ma twórczy charakter. Jego dominującymi elementami są forma i obraz. Oddziaływanie na odbiorcę dokonuje się w nich dzięki operowaniu analogicznymi jak w oryginale środkami ekspresji artystycznej. W przeciwieństwie do tekstów naukowych są niejednoznaczne lub ostentacyjnie wieloznaczne (Wawrzyniak 1991: 129 i 133). 
Tłumaczenie tekstów nieliterackich niesie ze sobą wymóg znajomości terminologii i odpowiadającego jej systemu pojęciowego w języku oryginału i w języku przekładu. Powinno być dokładne i jednoznaczne, albowiem podstawową cechą tekstów nieliterackich w zakresie leksyki są terminy. Teksty te maja jednakże na celu nie tylko przekazanie informacji czy wiedzy na określony temat, ale zachowanie obrazu świata w ujęciu autora, sposobu objaśnienia zjawisk, struktury myśli, toku wywodu, sposobu widzenia itd. (Kozłowska 2007: 55-56).

Już definicja przekładu tekstu nieliterackiego (w tym naukowego) implikuje jego transformację. Jest to bowiem: ,przekazanie w tekście wyrażonym środkami języka $\mathrm{J}_{2}$ informacji zawartej $\mathrm{w}$ tekście oryginału ( $\mathrm{w}$ języku $\mathrm{J}_{1}$ ) przy zachowaniu poprawności językowej przekładu. Możliwe jest przy tym dodanie informacji potrzebnej do zrozumienia intencji autora przez odbiorcę terminalnego, którego zasób wiedzy jest inny niż zasób wiedzy odbiorcy prymarnego oraz pominięcie informacji zbędnej dla odbiorcy terminalnego" (Kozłowska 2007: 42-43). Tłumaczenie tekstu nieliterackiego dopuszcza zatem: brak ekwiwalencji (nietłumaczenia pewnych elementów tekstu jak, np. terminów, cytatów i pozostawianie ich w oryginalnej postaci), a także wprowadzanie zmian, dodawanie uzupełnień, komentarzy, dotyczących zwykle trudności tłumaczeniowych, kwestii warsztatowych, modyfikacji względem tekstu oryginału etc. Zmiany są osiągane za pomocą różnych technik tłumaczeniowych, np. uzupełnień (m.in. objaśnień zwrotów obcojęzycznych lub terminów), opuszczeń, zamian (substytucji) (Kozłowska 2007: 68).

W świetle przedstawionych teorii tekst koraniczny reprezentowałby zarówno typ tekstu literackiego (funkcja estetyczna języka i dialogowość), jak też nieliterackiego, specjalistycznego (aspekt logiczny języka).

Można postawić tezę, iż praca tatarskich translatorów Koranu w zakresie przyjętych strategii translatorskich, wybranych metod i sposobów tłumaczenia oraz implikowanego przez nie stopnia transformacji oryginału wpisuje się w zasady przekładu tekstu naukowego humanistycznego. Tekst humanistyczny spełnia wymogi tekstu naukowego, a ponadto w związku ze zmianą paradygmatu naukowego zauważalna jest w nim tendencja do używania języka emocjonalnego, ekspresywnego z elementami potocznego. Obecne w nim terminy nie mają wyraźnie oznaczonych granic, ich odniesienie przedmiotowe zależy od kontekstu. Są często wieloznaczne i niepozbawione elementów oceniających i ekspresywnych czy ideologicznych (Gajda 1990: 43). Zwykle 
nie mają dokładnych definicji, ale nazywają świadomie stworzony element wiedzy specjalistycznej (Nikitina 1987: 28). W danym tekście mogą współistnieć terminy oznaczające to samo pojęcie i tworzyć szeregi synonimiczne. Teoretycy przekładu zauważają ponadto analogie między przekładem tekstu literackiego, zawierającego terminologię z danej dziedziny a przekładem tekstu naukowego humanistycznego (Kozłowska 2007: 75).

Jako przykład posłuży tłumaczenie terminologii muzułmańskiej związanej z Dniem Sądu Ostatecznego. Materiał leksykalny wyekscerpowano z Tefsiru z 1725 r. (transliteracja Meredith-Owens, Nadson 1970: 141-176; Suter 2004: 374-446) i Tefsiru z 1788 r. (transliteracja w rękopisie - Łapicz). Są to kopie powstałego w 2. połowie XVI wieku przekładu Koranu na język polski, mającego postać tefsiru (z ar. تفسير tafsīr 'komentarz, wykładnia, objaśnienie'), czyli komentarza oryginalnego tekstu arabskiego, co było zgodne

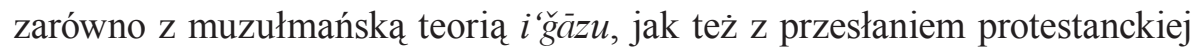
szkoły przekładów Pisma świętego, która postulowała odejście od zasady verbum de verbo fidellisime reddere, sformułowanej przez Sykstusa ze Sieny w podręczniku nauk biblijnych - Bibliotheca sancta, Wenecja 1566, czyli sporządzania imitacji (dosłownego kopiowania słów i konstrukcji oryginalnych języków biblijnych) na rzecz przekładów ad sensum, czyli według zasady reddere non verbum verbo, sed sensum sensui.

Przekład tekstu koranicznego charakteryzuje się zatem zarówno wiernością wobec oryginału, wyrażającą się m.in. brakiem ekwiwalencji, czyli nietłumaczeniem pewnych elementów tekstu, jak np. terminów, cytatów i pozostawianiem ich $\mathrm{w}$ oryginalnej postaci, jak również licznymi modyfikacjami arabskiego źródła.

Oryginalne terminy muzułmańskie i nazwy własne, odnoszące się do centralnych pojęć religii islamu są w nim translokowane lub slawizowane. Ich obecność jest świadectwem świadomości translatorskiej na temat nieadekwatności czy nieprzekładalności terminologii stricte muzułmańskiej. Ponadto wyraża dążenie do dosłowności, precyzji w nominowaniu desygnatów ze świata religii i kultury islamu, a także jest zgodna z przyjętą przez tatarskich translatorów strategią tłumaczeniową - autentyzmem przekazu (por. przekład metodą cytatu - quotational translation), dzięki czemu odbiorca uzyskuje dostęp do pierwotnego bodźca i może go samodzielnie interpretować. Stanowi również potwierdzenie wagi tekstu oraz świadomości języka 
arabskiego, którego formy starano się wiernie oddawać1. W tatarskim tefsirze przykładem nazwy slawizowanej, dla której translator nie znalazł odpowiednika leksykalnego i semantycznego jest, np. 'ejjam-ul-mulach 'czas określony; Dzień Sądu Ostatecznego' (Woronowicz 1935: 357) z ar. يوم yawm 1. 'dzień; doba'; 2. pl. 'czas, okres; życie' (Danecki, Kozłowska 1996: 803) + ar. الملح 'al-mulaḥ 'słony’ (Danecki, Kozłowska 1996: 721 z ar. malaha 'być słonym, stawać się słonym').

Jednoznaczności i precyzji przekazu służą również liczne transformacje tekstu oryginalnego. Są to zmiany motywowane dążeniem do zwiększenia komunikatywności tekstu, przy jednoczesnym zachowaniu rygoryzmu translatorskiej dokładności. Dotyczą rodzimej ekwiwalencji dla oryginalnej terminologii islamu.

$\mathrm{Na}$ zwiększenie stopnia zrozumiałości przekładu ma zatem wpływ, np. swobodne podejście do oryginału, czyli tłumaczenie ad sensum. Polega ono na oddawaniu nie tyle poszczególnych słów, ile myśli zawartych w poszczególnych wersetach. Zakładana dowolność językowo-stylistyczna nie może jednakże naruszać właściwego sensu oryginału (zachowanie niezmienionego sensu źródła) i rozumienia pojęć doktrynalnych. W przekładzie Tatarów Wielkiego Księstwa Litewskiego (dalej: WKL) można wskazać liczne wykładniki przekładu swobodnego. Należy do nich, np.: różnicowanie znaczeń wyrazów w zależności od kontekstu (tzw. rozwinięcie logiczne), prowadzące do oddawania arabskiej jednostki językowej różnymi słowiańskimi odpowiednikami - por. uniwerbalizacje (ich następstwem jest obecność w tatarskim tefsirze szeregów synonimicznych) takie jak *den sondnij powstanij (T1 fol. 27b, w. 5b, s. 423) z ar. يوم yawm + ar. القيامة al-qiyāma[t] 1. rel. 'zmartwychwstanie'; 2. 'opieka'; 3. 'popłoch, panika, zgiełk, zamieszanie, rwetes' (Danecki, Kozłowska 1996: 613) oraz *den pōwstanij i *čas ōstatnij (T1 fol. 6b, w. 1b, s. 380), a także *den ōstatnij (T1 fol. 23b, w. 2b, s. 414) z ar. اليوم al-yawm + ar. الآخر al-āhir 'ostatni, końcowy' (Danecki, Kozłowska 1996: 18), znak'i cuda (T2 II, w. 8, s. 72) z ar. بية bayyina[t] 'jasny dowód, bezsporne świadectwo'

1 Suter (2004: 56-66) potwierdza, iż muzułmański translator pozostawiał terminy „teologicznie istotne” (70 z nich odnosi się do centralnych pojęć religii islamu) w formie oryginalnej z powodu braku odpowiedników w języku przekładu. Do najczęściej używanych arabizmów zalicza: farḍ, kāfir, šayțān, zakā, ẓālim oraz formułę wyznania wiary lā ilāha illā llāh i termin gāāì. Przytacza również używane w T1 - z niższą frekwencją niż arabizmy - turcyzmy i wyrazy perskiego pochodzenia. 
(Danecki, Kozłowska 1996: 155), *zbawene *spasंene lüdzem *ūspōkōjene grechōw (T1 fol. 18a, w. 4b, s. 403) z ar. مثبت mutbat 'ustalony, pewny, stały, gotowy' (Danecki, Kozłowska 1996: 660) + ar. J li I. przyimek 1. 'dla'; 2. 'przynależność, własność, posiadanie’; 3. ‘do, ku, w kierunku’ II. spójnik 1. 'żeby, aby, ażeby'; 2. 'niech, oby’ (Danecki, Kozłowska 1996: 631) + ar. ناس nās 'ludzie' (Danecki, Kozłowska 1996: 743) + ar. أمن amn 'spokój, pewność, bezpieczeństwo' (Danecki, Kozłowska 1996: 99) czy *ratūnek *wspōmōžene (T1 fol. 18a, w. 1b, s. 402) z ar. نصر naṣara 1. 'pomagać, udzielać pomocy, dopomagać, wspomagać'; 2. 'przynosić zwycięstwo (o Bogu)'; 3. 'ratować, chronić, bronić' (Danecki, Kozłowska 1996: 756). Są one często wprowadzane w formie glos wewnątrztekstowych, pełniących funkcję objaśnień oryginalnej terminologii koranicznej. Wprowadzanie aparatu krytycznego, czyli glos, dopisków, komentarzy meta- lub pozatekstowych do przekładu to kolejna cecha tłumaczenia tekstu naukowego humanistycznego. W tatarskim piśmiennictwie przekładowym wyróżnia się dwa typy glos: zewnątrztekstowe (dopiski systematyzujące, uzupełniające, kronikarsko-rodzinne, w tym także autorskie, donacyjne oraz właścicielskie), porządkujące obszerne rękopisy od strony technicznej oraz uzupełniające je o pożądane przez użytkowników dodatki niezwiązane bezpośrednio z tekstem Koranu oraz wewnątrztekstowe (interpretacyjne, objaśniające, nawiązujące, korygujące), dotyczące bądź bezpośrednio, bądź tylko pośrednio, tekstu i koranicznych treści (Łapicz 2008: 71-77). Innym wykładnikiem swobodnego tłumaczenia jest uzupełnianie tekstu przekładu objaśnieniami trudnych pojęć, oryginalnych imion własnych oraz innych nominacji obcego pochodzenia, sygnalizując i konkretyzując tym samym ich desygnację - por. ź 'erefat' gōrī (T1 fol. 26b, w. 1b, s. 421) z ar. من min 'z, od, spośród, należący do, wywodzący się z' (Danecki, Kozłowska 1996: 725) + ar. عرفات 'arafat 'góra w okolicach Mekki', a także stosowanie omówień jako jednego ze sposobów oddawania obcych terminów - por. amplifikacje, po które sięgano ze względu na brak jednowyrazowych ekwiwalentów w języku przekładu, np.: *ten den (T1 fol. 10a, w. 1b, s. 386; fol. 34b, w. 2b, s. 437) z ar. يوم yawm; *den sondnij (T1) z ar. اليوم al-yawma 'dziś, dzisiaj' (przykład za Drozd 1999: 149) czy *matrika bōža (T1 fol. 354b, w. 6, s. 111) z ar. كتاب kitāb 'księga, pismo, dokument' (Danecki, Kozłowska 1996: 618). Dla nawiązania bezpośredniego kontaktu z odbiorcą tatarski tłumacz wprowadzał tzw. modulanty znaczeń, czyli różne elementy ekspresywne, określenia wartościujące lub uwydatniające stosunek emocjo- 
nalny do poszczególnych osób czy zjawisk. Atrybutami, charakteryzującymi Dzień Sądu Bożego, wskazującymi jego szczególny charakter i podkreślającymi jego nieuchronność i grozę są przede wszystkim ostatni, sqdny i strasz$n y$ - por. *den sondnij (T1 fol.17a, w. 2b, s. 400), *ten den (T1 fol. 10a, w. 1b, s. 386), *den ōstatnij (T1 fol. 11b, w. 1b, s. 389)². Uzupełniano również przekład różnymi dopowiedzeniami i szczegółami ułatwiającymi zrozumienie sensu, np. przez wyraźniejsze niż w oryginale określenie podmiotu lub dopełnienia - por. ar. في 11 1. 'w, na, o (czymś)'; 2. 'w czasie, podczas'; 3. 'wśród, pośród' (Danecki, Kozłowska 1996: 582) + ar. كتاب kitāb - w matrice bōžej lewch-el-mechfüz (T1 fol. 354b, w. 6, s. 111) - niekiedy występujący w oryginale wyraz bądź wyrażenie Tatarzy oddają wprawdzie za pomocą słowiańskiego ekwiwalentu, ale jego znaczenie konkretyzuja przez podanie arabskiego terminu, którego nie ma w podstawie tłumaczenia. Tak więc glosą, objaśnieniem czy też bardziej konkretyzacją znaczenia - w niektórych kontekstach - są nie tyle słowiańskie odpowiedniki, ile arabska leksyka religijna), wyszczególnienie szerszego kontekstu, np. ōka za ōka nōs za nōs ūchōza $\overline{\boldsymbol{u}} \boldsymbol{c h \overline { o }} \boldsymbol{z} \overline{\boldsymbol{o}} \boldsymbol{m} \boldsymbol{b}$ z a zōmb (T1 fol. 89a, w. 7, s. 203), wprowadzanie do zdań z podmiotem domyślnym odpowiedniego rzeczownika $\mathrm{w}$ funkcji podmiotu, np. ar. قول qawl 1. 'mowa, mówienie'; 2. 'słowa'; 3. pl. 'zeznania' (Danecki, Kozłowska 1996: 612) od ar. تال [qāla] 'mówić, powiedzieć'; 'stwierdzić, skonstatować'; 'mówić coś przeciwko komuś, na kogoś' - rekl ibrahīm (T1 fol. 18a, w. 3b, s. 403), mowī muchemmed (T1 fol. 19b, w. 6b, s. 406), mow ja muchemmed (czyli mów o Muhammadzie!) (T1 fol. 28a, w. 5b, s. 424), umieszczanie w tekście przekładowym licznych objaśnień, sygnalizowanych metajęzykowym omówieniem tō jest, znači śe (to znaczy), np. ten korãn swentij wipisanij w skritō kśenga tō jest w lewchi l-mechfüz (T1 fol. 05a, w. 1b, s. 378) z ar. كتاب kitāb + ar. مكنون maknūn 'strzeżony ze względu na swoją wartość'; 'niezwykle cenny' (por. Danecki, Kozłowska 1996: 719 ‘skryty, ukryty, schowany, utajony'), ukonkretnianie wyrazów o znaczeniu przenośnym, np. wyrażenie *den südnij z tur. yarın 'azāāb 'jutro (czeka) zmartwienie' (por. ar. يوم yawm + ar. أتى atà 1. 'przychodzić, przybywać, przyjeżdżać'; 2. 'przynosić (coś); przywozić, przyprowadzać (kogoś)'; 3. 'robić coś, wykonywać coś, popełniać'; 4. 'kończyć, wykańczać (coś)'; 5. 'eliminować, niszczyć, zużywać, wyczerpywać' + ar. هـ hum

2 Przykłady z innych zabytków: sudnij den strašnij (Kitab z Kazania 64a, w. 7-8, s. 99); toho dna strašnoho (Kitab Milkamanowicza 193, w. 3-4, s. 140). 
1. zaimek 3. osoby pl rodzaju męskoosobowego: oni; 2. sufigowany zaimek 3. osoby pl: ich + ar. عذاب 'ad̄āb 'męka, cierpienie, tortura, męczarnia'; 'kara' - za Danecki, Kozłowska 1996: 27 i 776), a także stale powtarzające się cza-

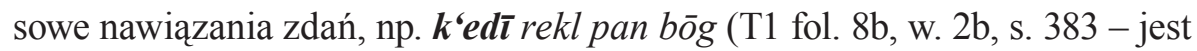
tu obecny tylko czasownik قال qāla o znaczeniu perfektywnym), mōwi ãnijōl (T1 fol. 12b, w. 7b, s. 392), etc.

Tłumaczenie ad sensum wyrażało zatem tendencję do uprzystępniania treści Koranu wiernym nieznającym języka arabskiego. Celem, który postawili sobie tatarscy translatorzy, była bowiem realizacja postulatu przybliżania wiedzy o treści ksiąg sakralnych, uczynienia ich przekazu jasnym, zrozumiałym, a zarazem wytłumaczenia, objaśnienia podstawowych kanonów wiary w językach słowiańskich, które rozumieli i którymi się posługiwali. Wykorzystywali w tym celu również nawiązywanie do żywej, codziennej mowy, czyli do języka potocznego, np. poprzez używanie deminutywów, współtworzących wizerunek nazywanych postaci (określony obraz referentów) - por. sinačkōwe (o synach Jakuba w T1 fol. 18b, w. 8b, s. 404), które poza pełnieniem funkcji identyfikującej (na podstawie stosunku pokrewieństwa) wnoszą dodatkową informację o uczuciach ich rodziców ${ }^{3}$, poprzedzanie zwrotu do adresata wykrzyknikiem ej (por. tur. partykuły ay! ey!) i obecność nominacji wokatywnych - por. aj sinačkōwe (T1 fol. 18b, w. 8b, s. 404). W oryginale ar. jest połączenie partykuły wołacza Ł yā 'o!, hej!' (Danecki, Kozłowska 1996: 798) z rzeczownikiem ابن ibn 'syn, potomek' (Danecki, Kozłowska 1996: 23) w pl. Tatarscy translatorzy używają zatem osobliwego ekwiwalentu synaczek, znanego z Biblii brzeskiej i z Biblii w przekładzie ks. Jakuba Wujka, w których należy do hapaks legomena.

Do modyfikacji tekstu źródłowego zaliczyć można również oddawanie oryginalnej konstrukcji składniowej status constructus jako rzeczownika z przydawką przymiotną, np. *den sōndnij (por. T1 fol. 5b, w. 3b, s. 379) i *den powstanij z ar. يوم yawm + ar. الدين ad-dīn rel. 'Dzień Sądu Ostatecznego' lub również *den sōndnij (por. T1 fol. 17a, w. 2b, s. 400) oraz *den sondnij powstanij (por. T1 fol. 27b, w. 5b, s. 423) z ar. يوم yawm + ar. القيامة al-qiyāma[t]. U Tatarów WKL widoczna jest wyraźna tendencja do usuwania przydawki dopełniaczowej na rzecz przymiotnej (wysoka frekwencja R[Pp świadczy

3 Zdrobnienia pełniły bowiem również funkcję emocjonalną, mającą angażować uczuciowo czytelnika i wydobywać, a następnie wyrażać za pomocą stosownego wyrazu tkwiącą w tekście oryginalnym ekspresywność bądź mu ją nadawać. 
o przyjętej przez tatarskich tłumaczy metodzie translatorskiej) ${ }^{4}$. Większość przydawek to przymiotniki urobione od rzeczownikowego odpowiednika ar. członu określającego (adjektywizacja). Następstwem adjektywizacji drugiego członu jest powstanie neologizmu *den powstanij (T1 fol. 27b, w. 5b, s. 423) zamiast dzień powstania (zmartwych).

W oddawaniu arabskich konstrukcji składniowych tatarscy tłumacze czuwali zarówno nad zgodnością przekładu z kanoniczną wersją, jak też nad zachowaniem zasad języka tłumaczenia, co przysparzało im wielu problemów, np. pełniące w tekście arabskim funkcję przysłówka przymiotniki lub rzeczowniki w bierniku stanu nieokreślonego oddawali przez formy przysłówkowe, rodzime wyrażenia przyimkowe bądź typowe dla staropolszczyzny i języka kresowego konstrukcje syntetyczne (okolicznik wyrażony przez narzędnik), np. ar. اليوم al-yawma 'dziś, dzisiaj' - Dna sondnego (T1).

Odejście od tekstu oryginalnego dokonuje się w tatarskiej praktyce przekładowej również przez zastępowanie oryginalnej terminologii koranicznej terminologią o chrześcijańskim rodowodzie. W piśmiennictwie tym obecna jest zatem chrześcijańska leksyka religijna, w tym frazeologia o proweniencji biblijnej - z reguły - o innej intensji lub ekstensji. Jej funkcjonowanie w tatarskich tekstach przekładowych opiera się bardziej na analogii translacyjnej niż na adekwatnym i zgodnym z doktryną islamu zastępowaniu terminów muzułmańskich terminami z kręgu religii i kultury chrześcijańskiej. Są to zmiany motywowane dążeniem do zwiększenia komunikatywności tekstu, przy jednoczesnym zachowaniu rygoryzmu translatorskiej dokładności, np. *den sondnij (np. T1 fol. 27b, w. 5b, s. 423) - por. Gn $2^{5}$ Dzień Sqdny (SStp); dzień sqdny, sqdu (Bożego a. Pańskiego) OpecŻyw 193; BielŻyw 97; WróbŻołt S 5; RejPs Ff3; Leop Is 66 arg; BibRadz 4.Esdr 12/34; WujJud 8, 238 i szereg innych < łc. dies ultimus; dies iudicii (za SPolXVI VI, 402), dzień sqdny (SMick II, 332), sqdny dzień (SL I, 604 i SDor II, 581) oraz polskie translacje Biblii - por. NT Mt 10, 15 (BB, BN, BW, BG); *ten den (np. T1 fol. 10a, w. 1b, s. 386) - por. NT Łk 19, 42 (BB, BN, BW, BG, BT) oraz ST Jr 25, 33; 46, 10 (BT); *den östatnij (np. T1 fol. 23b, w. 2b, s. 414) - por. ST Pwt 4, 30;

${ }^{4}$ Oryginalna arabska konstrukcja składniowa status constructus (ar. iḍāa) w tłumaczeniu przyjmuje najczęściej dwie postacie: rzeczownika z przydawką dopełniaczową (R[Pd) lub rzeczownika z przydawką przymiotną (R[Pp), za Drozd 1999: 137.

5 Rozwiązanie skrótów cytowanych zabytków znajduje się w historycznych słownikach języka polskiego. 
Am 8, 10 (BG, BT); NT Dz 2, 17 (BN, BW, BG, BT) oraz dzień ostateczny, ostatni w KrowObr 1v; KuczbKat 60; BiałKaz D4 oraz CzechEp 15, 46; LatHar 356; WujNT 104, 837 etc. (za SPolXVI VI, 402).

Koran to heterogeniczna księga sakralna o charakterze Bożego Objawienia, odległa od europejskich kulturowych, religijnych i językowych realiów. Stawia więc translatorom wymóg zarówno możliwie największej filologicznej wierności, jak też możliwie najpełniejszej komunikatywności przekazu. Tatarski tefsir cechuje autentyzm - wysoki stopień nasycenia realiami tekstu wyjściowego (np. zachowanie obcej terminologii), a zarazem adaptacja, której rezultatem jest kompensowanie różnic kulturowych - tłumacz tworzy sytuację, która może być uznana za ekwiwalentną, wykorzystując przy tym również narzędzia pozatekstowe (komentarze, glosy etc.). Następstwem adaptacji są przesunięcia i transformacje niezbędne do zachowania wierności przekazu, służące jego jednoznaczności i precyzji. Wprowadza się je chociażby ze względu na nieadekwatność słowiańskich leksemów wobec ich arabskich odpowiedników oraz polisemię arabskich podstaw translacyjnych.

\section{Wykaz skrótów}

BB - Biblia brzeska (1563), 2003, Clifton-Kraków: Kalwin Publishing i Collegium Columbinum.

BG - Biblia gdańska (1632), Nowy Testament, 1996, Kraków: Wydawnictwo „Na Straży”; Stary Testament, 2004, Kraków: Wydawnictwo „Na Straży”.

BN - Biblia nieświeska (1572), Nieśwież: starodruk ze zbiorów Biblioteki Uniwersytetu Warszawskiego.

BT - Biblia Tysiqclecia, 1980, Poznań-Warszawa: Pallottinum.

BW - Biblia w przekładzie ks. Jakuba Wujka (1599), 2000, transkrypcja typu B tekstu oryginalnego z XVI w., Warszawa: Oficyna Wydawnicza VOCATIO.

NT - Nowy Testament

SDor - Doroszewski W. (red.), 1958-1969, Słownik jezzka polskiego, t. 1-11, Warszawa: Państwowe Wydawnictwo „Wiedza Powszechna”, PWN.

SL - Linde S. B., 1854-1860, Stownik języka polskiego, t. 1-6, Lwów: Zakład Narodowy im. Ossolińskich.

SMick - Górski K. (red.), 1962-1983, Słownik języka A. Mickiewicza, t. 1-11, Wrocław-Warszawa-Kraków: Zakład Narodowy im. Ossolińskich. 
SPolXVI - Mayenowa M. R., Pepłowski F. (red.), 1966-, Słownik polszczyzny XVI wieku, t. 1-35, Wrocław-Warszawa-Kraków-Łódź: Zakład Narodowy im. Ossolińskich, Wydawnictwo IBL PAN.

ST - Stary Testament

SWil - Zdanowicz A. (red.), 1861, Słownik języka polskiego, t. 1-2, Wilno: Wydany staraniem i kosztem Maurycego Orgelbranda.

$\mathrm{T} 1-$ Tefsir z $1725 \mathrm{r}$.

$\mathrm{T} 2-$ Tefsir z $1788 \mathrm{r}$.

\section{Bibliografia}

Danecki J., KozŁowska J., 1996, Słownik arabsko-polski, Warszawa: Wiedza Powszechna.

DROZD, 1999, Arabskie teksty liturgiczne w przekładzie na język polski XVII wieku. Zagadnienia gramatyczne na materiale chutb światecznych, Warszawa: Dialog.

GAJDA S., 1990, Wprowadzenie do teorii terminu, Opole: WSP.

Grucza F., 1981, Zagadnienia translatoryki, w: F. Grucza (red.), Glottodydaktyka a translatoryka, Warszawa: WUW, s. 9-29.

Kielar B. Z., 1988, Ttumaczenie i koncepcje translatoryczne, Wrocław-Warszawa-Kraków-Gdańsk-Łódź: Ossolineum.

KozŁowska Z., 2007, O przekładzie tekstu naukowego. Na materiale tekstów językoznawczych, Warszawa: Wydawnictwa Uniwersytetu Warszawskiego.

ŁAPICz C., 2008, Glosy, komentarze, objaśnienia etc., czyli o pozakoranicznych dopiskach w rękopiśmiennych tefsirach muzułmanów Wielkiego Księstwa Litewskiego, w: T. Bairašauskaitė, H. Kobeckaitė, G. Miškinienė (red.), Orientas Lietuvos Didžiosios Kunigaikštijos Visuomenès Tradicijoje: Totoriai ir Karaimai, Vilnius: Vilniaus Universiteto Leidykla, s. 69-80.

Meredith-Owens G. M., Nadson A., 1970, The Byelorussian Tartars and their Writings, The Journal of Byelorussian Studies II, nr 2, s. 141-176.

Nikitina S. E., 1987, Semanticheskijj analiz jazyka nauki. Na materiale lingvistiki, Moskva: Nauka.

ReISs K., 1976, Texttyp und Übersetzungsmethode. Der operative Text, Kronberg: Scriptor.

Suter P., 2004, Alfurkan Tatarski. Der litauisch-tatarische Koran-Tefsir, Köln-Weimar-Wien: Böhlau Verlag.

WAWrZyNiAK Z., 1991, Praktyczne aspekty translacji literackiej na przykładzie języków niemieckiego i angielskiego, Warszawa: Państwowe Wydawnictwo Naukowe. 
Woronowicz A., 1935, Kitab Tatarów litewskich i jego zawartość, Rocznik Tatarski II, s. $376-394$.

\section{Transformation as an immanent feature of the translation of a specialized text - based on Polish translation of Koran of the second half of the sixteenth century}

\section{( s u m mary)}

The article puts forward a thesis that the work of Tatar translators of Koran in the second half of the sixteenth century, within the scope of the received interpreter's strategies, chosen methods and ways of translation, and the degree of the original's transformation implied by them, suits the rules of scholarly, humanistic text. Exemplary evidence is provided by Muslim terminology excerpted from two copies of original Tatar tefsir. It is pointed out that the translation of Muslims' holy book is characterized both by faithfulness to the original, expressed (among other things) by the lack of equivalence, and also by many modifications of the Arabic source. Those features are considered to be important indicators of the translation of a specialized text. 
